\title{
Political risk management practices of Multinational Corporations: their approaches to deal with developing countries under economic sanctions
}

\begin{abstract}
This article explores adjustments to the traditional political risk management practices followed by Multinational Corporations (MNCs) in their international operations to incorporate an increasingly concerning risk arising from the more frequent imposition of economic sanctions on developing countries over the last ten years for political purposes. In order to identify the main determinants of this risk and its consequences, a literature review is conducted, highlighting the models proposed by Tsebelis (1990) and Kakutami (2017) as the main frameworks to understand the dynamics for sanctions impositions, their frequency and the management of this risk by traditional MNCs from developed countries. Kakutami's model is further enhanced in this article with a game theoretical model to understand the dynamic behavior of MNCs under this context, considering evidences of a growing presence in international markets of MNCs from developing countries, whose motivations for their expansion are explored. Finally, different political risk mitigating strategies are reviewed to explore their suitability to MNCs, with particular emphasis on the use of insurance to cover this risk and its effects on MNCs' willingness to engage with sanctioned countries. As a general finding, from a reputational point of view, MNCs should take a more active role in their network analysis to identify their direct and indirect exposure to this risk, given the more frequent imposition of sanctions with an extraterritorial reach.
\end{abstract}

Keywords: Political Risk; Economic Sanctions; Multinational Corporations; Developing Countries; Least-Developed Countries; Emerging Market Countries; Games Theory

Corresponding author: e-mail: ygonzale@ucab.edu.ve

Received 21 July 2019 - Accepted 25 March 2020

This is an Open Access article distributed under the terms of the Creative Commons Attribution-Non-Commercial-No Derivatives License (http://creativecommons.org/licenses/by-nc-nd/4.0/), which permits non-comercial re-use and distribution, provided the original work is properly cited, and is not altered or transformed in any way. 


\section{Introduction}

The study of the political risk management practices by Multinational Corporations (MNCs), mostly from developed countries, in their dealings with developing countries ${ }^{1}$ has been mainly focused on risks arising from these countries, especially due to actions taken by their own States and other local actors, such as expropriations, local regulations, etc. Little attention has been placed by the academic literature on political risks related to those countries but arising from abroad (Brink 2004; Gregory 1988). Among the latter group of risks, MNCs' trade and investment relations with developing countries have been recently challenged by the more frequent imposition of international economic sanctions with an extraterritorial reach by foreign governments and other international entities (senders) for political purposes on a growing number of governments of non-developed countries (targets) ${ }^{2}$ over the last ten years. This is a growing area of concern for MNCs as reflected in recent surveys, such as the annual Political Risk Survey Reports published by Oxford Analytica and Willis Towers Watson, which places country sanctions as one of their top three political risks in 2019, ahead of other traditionally researched political risks.

Giving this evidence, this article is aimed at establishing an integrated framework, based on the review of the existing literature on country economic sanctions and their modelling, which

\footnotetext{
${ }^{1}$ Countries are classified from developed to developing countries according to their income per capita and other measures related to their inhabitants' life quality summarized in the Human Development Index (HDI), with developed countries reporting the highest values in those dimensions. Developed countries report HDIs above 0.8 (in a range from 0 to 1) and high income per capita, set above USD 12,376 according to the World Bank (2018). All other countries are deemed as developing countries (International Monetary Fund 2015) ranging from emerging market countries (displacing traditional activities from the agriculture and raw materials exports to more technologically advanced activities) to least developed countries (with mostly traditional economic activities, constraints for their sustainable economic growth and income per capita below USD 1,025 in 2018 as per the World Bank).

${ }^{2}$ In the academic literature, the sanctioning and the sanctioned parties are respectively known as "the sender" and "the target" (Kaempfer and Lowenberg 2007).
} 
can be used by MNCs to face this emerging risk concern before and after their imposition (Kakutami 2017; Tsebelis 1990).

The setting of this integrated framework for MNCs will also consider its relevance to the specific characteristics of MNCs from developed and developing countries. From this perspective, the traditional literature on MNCs has described them as entities from capital exporting developed countries that display converging political, economic, legal, environmental and social systems, posing little risk for MNCs entering into these markets.

On the other hand, within the context of developing countries, a new group of MNCs is arising from emerging market countries over the last 30 years through the process of economic globalization, procuring their international expansion with more flexible approaches that differ from those applied by MNCs from developed countries. Those distinctive approaches to deal with target countries will be also reviewed to identify their motivations.

In order to understand the MNCs' behavior risking likely penalties by senders due to their dealings with targets, the original static model proposed by Kakutami (2017) to explain this behavior will be further adjusted through a game theoretical approach to explain the dynamics of the interactions between MNCs and senders.

The practical implementation of these strategic moves by MNCs will also involve the review of different tactics to mitigate their expected loss impact through their retention, avoidance or transfer of this risk. These tactics will be analyzed to discuss their relative usefulness for MNCs in the management of their operations with targets from developing countries, with particular attention to understand the effects of the use of insurance to cover this risk on the 
behavior of insured MNCs based on an extension to the game theoretical model proposed by Tsebelis (1990).

\section{Economic sanctions: characteristics and effects}

Economic sanctions have been used by international organizations such as the United Nations and different sovereign states to obtain desirable political and humanitarian changes in their sanctioned targets. Those targets are generally sovereign states and can also include companies, non-profit organizations, groups (such as terrorists, drug dealers, cybercriminals and the alike) and individuals. The most frequent goal to impose these sanctions over the period 1914-2000 (Hufbauer et al. 2007) corresponded to political regime changes and subsequent democratization, representing $39.22 \%$ of cases, especially against regimes that maintained a hostile stance toward the sender. Other frequent goals were aimed at causing modest policy changes $(21.08 \%)$ that do not represent a change of the target's government, other major policy changes (16.18\%), military impairment to prevent a potential powerful hostile regime (14.22\%) and disruption of military adventures undertaken by the target $(9.31 \%)$

In general, the imposition of sanctions for political aims can take different types, namely:

a. Trade sanctions: measures to limit trade relationships with the target, especially to reduce its exports to the sender or to the rest of the world through the imposition of trade quotas, higher tariffs, import licenses in the sender's country as well as to limit the sender's exports to the target.

b. Financial sanctions: comprising the seizure of the target's assets abroad as well as restrictions on investment and financial transactions with the target such as mandatory disinvestment, suspension or restrictions on lending and payments related to the target, etc. 
c. Targeted sanctions: such as travel, transportation and communications bans.

d. Embargoes: aimed at prohibiting all kind of dealings with the target.

Hufbauer et al. (2007) found a success rate of 34\% for imposed country sanctions for political reasons during the period 1914-1990. Morgan et al. (2009) enhanced the research on sanctions' success by including sanctions threats in 888 cases of sanctions threats and impositions during the period 1971-2000 finding a success rate of 35\% for imposed sanctions and $45 \%$ for sanctions threats that were not finally imposed.

It is important to distinguish these kinds of sanctions for political aims from sanctions that emerge due to international trade breaches as well as from new sanctions proposals based on violation to environmental issues according to the 2016 Paris Climate Agreement. ${ }^{3}$ These violations are dealt with economic countermeasures by the sanctioning party, mainly imposing compensating trade barriers, rising import duties, etc., until the sanctioned party changes its unfair trade practices, without procuring any political change from its part (Stanglin 2010). ${ }^{4}$ Some of these trade countermeasures can be avoided by MNCs from the target by setting local operations as subsidiaries in the sanctioning country to supply its market and to circumvent these higher import duties. This strategy is totally unpractical in a context of economic sanctions for political / humanitarian purposes as these consider that any kind of trade or investment deal with the target is illegal with an extraterritorial reach beyond the sender's jurisdiction. The dynamic interaction between sender and target countries before any sanction enforcement has been described under game theoretical frameworks by authors

\footnotetext{
3 Colman, Zack. 2019. "Europe threatens U.S. with carbon tariffs to combat climate change." Politico.com, December 13. Accessed March 20, 2020. https://www.politico.com/news/2019/12/13/europe-carbon-tariffclimate-change-084892.

${ }^{4}$ Stanglin, Doug.2010. "Brazil slaps trade sanctions on the U.S. to retaliate for subsidies to cotton farmers." USA $\begin{array}{llllll}\text { Today, } & \text { March } & \text { 9. } & \text { Accessed } & \text { March } & 2020 .\end{array}$ http://content.usatoday.com/communities/ondeadline/post/2010/03/brazil-slaps-trade-sanctions-on-us--toretaliate-for-subsidies-to-cotton-farmers/1\#.XILiYShKjIU
} 
such as Tsebelis (1990) with further refinements by Pradiptyo (2007). The use of game theoretical models is considered as suitable to describe this risk as it involves different strategic actions and reactions between its players, yielding different outcomes. Tsebelis (1990), considered a $2 \times 2$ game between a sender country and a target country. The target country follows two strategies: to violate the international law or to comply with it; whereas the sender country can choose two strategies: to enforce and not to enforce sanctions on the target. Under this game, no player follows a particular strategy with probability equal to one. Assuming complete information, rationality, continuous choices and simultaneous moves, Tsebelis determines the probabilities for the target's compliance (x) and for the enforcement of sanctions by the sender (y), from the following matrix in Table 1:

Table 1. General payoff matrix for the sender and target countries

\begin{tabular}{|l|c|c|c|}
\hline & & \multicolumn{2}{|c|}{ Sender } \\
\hline & & Sanction & No sanction \\
\hline Target & Violate & $\mathrm{a}_{1}+\mathrm{e}_{1} \mathrm{x} ; \mathrm{a}_{2}+\mathrm{e}_{2} \mathrm{y}$ & $\mathrm{b}_{1}+\mathrm{e}_{1} \mathrm{x} ; \mathrm{b}_{2}$ \\
\hline & Comply & $\mathrm{c}_{1} ; \mathrm{c}_{2}+\mathrm{e}_{2} \mathrm{y}$ & $\mathrm{d}_{1} ; \mathrm{d}_{2}$ \\
\hline
\end{tabular}

Source: Tsebelis (1990).

The terms $\mathrm{a}_{1}, \mathrm{~b}_{1}, \mathrm{c}_{1}$ and $\mathrm{d}_{1}$ represent the average payoffs to the target under different scenarios adjusted by the asymmetric information correction factor $\mathrm{e}_{1}$ (if the payoffs to the target are unknown to the sender) whereas $\mathrm{a}_{2}, \mathrm{~b}_{2}, \mathrm{c}_{2}$ and $\mathrm{d}_{2}$ are the payoffs to the sender adjusted by the asymmetric information correction factor $\mathrm{e}_{2}$ (if the payoffs to the sender are unkown to the target). In equilibrium, the probabilities $\mathrm{x}^{*}$ and $\mathrm{y}^{*}$ are obtained as follows:

Optimal target's compliance probability $\left(\mathrm{x}^{*}\right)$ :

$$
x^{*}=\left(d_{2}-c_{2}-e_{2} y\right) /\left(d_{2}-c_{2}-e_{2} y+a_{2}+e_{2} y-b_{2}\right)
$$

Optimal sender's sanctions imposition probability $\left(\mathrm{y}^{*}\right)$ :

$$
y^{*}=\left(b_{1}+e_{1} x-d_{1}\right) /\left(b_{1}+e_{1} x-d_{1}+c_{1}-a_{1}-e_{1} x\right)
$$


When the terms $e_{1}$ and $e_{2}$ are equal to 0 , then, both players are playing under conditions of complete information, rationality, continuous choices, and simultaneous moves. If one of these players chooses a strategy different to $x^{*}$ and $y^{*}$, the other party has incentive to change his strategy, keeping simultaneous actions and counteractions between the parties. According to these results, the sender country is unable to affect the target country's compliance probability $\left(\mathrm{x}^{*}\right)$ by influencing the target's payoffs under the different scenarios described in Table 1. On the other hand, the probability expressed in (II) should be taken into account to determine the expected loss for an MNC due to sanctions impositions on its dealings with a target country. This loss probability depends on the perceived payoffs to the target (violator) country under different scenarios.

\section{New MNCs players in sanctioned countries: the increasing presence of Emerging Markets MNCs (EMNCs)}

The growth of different emerging market countries over the last 30 years has favored the transformation of their local corporations into large MNCs, best known as Emerging Market Multinationals (EMNCs). The increasing presence of these EMNCs is reflected in the Fortune Global 500 list of firms according to their revenues in 2015 where $30 \%$ of these firms are EMNCs versus $10 \%$ ten years ago. By 2019, EMNCs from China have a leading representation in this list, with 119 companies, followed by corporates from Brazil, India, Indonesia, Korea, Mexico and Russia among other seven emerging market countries (Mourdoukoutas 2019).

These EMNCs tend to invest in regional markets with some kind of cultural affinity with the EMNCs' countries of origin, with fewer concerns for political risks and place more importance on their revenues growth in their current overseas expansion phase rather than on 
their profit margins, which is the focus for MNCs from developed countries (Gomez-Mera et al. 2014). At the same time, the internationalization of EMNCs from 20 top emerging market countries has contributed to $20 \%$ of the current global outward investment flows in 2015 in comparison to $2 \%$ at the end of the twentieth century (Casanova and Miroux 2016). Many leading EMNCs are characterized by a relatively higher labor intensity in their production techniques as it is the most abundant production factor (rather than capital) in their countries of origin. The use of labor intensive techniques leads EMNCs to procure their entry into foreign markets with high levels of labor supply to be used in combination with their technologies (Tolentino 2012). Their entry into targets with high labor intensity contributes with the target's efforts to achieve autarky conditions for their local supply of goods and services.

These EMNCs have mainly addressed their international expansion by using innovative and eclectic business models, which are suitable to the unstable economic and political conditions of developing countries as these corporates are used to similar problems in their countries of origin. This practice makes them comfortable to engage in less transparent business practices aimed at obtaining benefits from local authorities in their countries of operations, as denounced by Transparency International (2016).

At the same time, EMNCs can leverage their presence in new markets by recurring to mergers and acquisitions (M\&A) of local companies to obtain faster access to local know-how and social capital (networking) with connections to key political entities that can grant them with privileges for their local operations. By contrast, MNCs from developed countries place their competitive advantages on the possession of key resources or in their leading positioning 
within their economic sectors, with more concern for their reputational risk (Madhok and Marques 2013).

In particular, EMNCs operating in regulated sectors such as utilities, etc., are more willing to engage in political negotiations with sanctioned targets as described by Garcia-Canal and Guillen (2008), who mention the entry experiences in Latin America of Spanish companies from regulated sectors in the period 1987-2000. These companies have been more inclined to invest in more politically unstable countries if their authorities have more discretionary decision-making processes to grant favorable entry conditions to these companies that otherwise should undergo relatively stricter entry conditions than the non-regulated ones if they attempt to enter into more stable developed countries with more regulated grating processes by their authorities.

On the other hand, many top EMNCs in the previous 2019 Fortune Global 500 list are StateOwned Enterprises (SOEs), such as Sinopec Group, China National Petroleum and State Grid from China, Gazprom and Rosneft from Russia, which is a condition that makes more difficult their international expansion through M\&A abroad. This restriction is due to the perception that SOEs from countries such as China have received subsidies to acquire targets abroad, which is considered as an unfair advantage under current international trade and investment standards. This practice led to reforms in the United States (US) and the European Union (EU) to control Foreign Direct Investment through changes to the Committee on Foreign Investment in the United States (CIFIUS) and the enactment of the EU framework for screening Foreign Direct Investment (FDI) in 2019 under the Regulation 2019/452 of the European Parliament. The EU framework for screening FDI has similar objectives as the CIFIUS (Adesnik and Ghasseminejad 2018). 
These restrictions in developed countries for SOEs from emerging countries have encouraged them to procure other counties for their investments and trade flows (Business and Sanctions Consulting The Netherlands 2019). As the number of sanctioned countries has recently increased, it is important to consider the economic weight of those sanctioned allied countries in relation to the economic weight of their senders to assess the success rate and likely duration of these sanctions, which should be taken into account by MNCs to decide whether to leave, enter or delay their entry into a sanctioned country. This new pattern of alliances should be also incorporated into empirical studies to assess its impact on sanctions duration and success rates, which have been previously focused on the comparison between the GNPs of a single target and its senders.

\section{Modeling MNCs' dynamic behavior to deal with country economic sanctions risk}

Based on the framework proposed by Kakutami (2017) and as a contribution to further understand the dynamic behavior of MNCs under country economic sanctions, this framework will be analyzed by analogy to the auditing games originally proposed by Rasmusen (2001) between tax authorities and taxpayers. The adjustment of these games to this political risk involves considering MNCs and senders as players sharing similarities with the behavioral patterns of taxpayers and tax authorities, respectively.

Under the sanctions game, an MNC evaluates two decisions: sanctions-bursting (SB) and sanctions compliance (SC). The sender considers two levels of observance on an MNC's sanctions compliance: high and low observance, which determines two levels of conspicuity detection for an MNC: high conspicuity (HC) and low conspicuity (LC).

An MNC faces a fine (F) if detected in SB and makes a decision to engage in this activity with a probability equal to $\alpha$. In parallel, the sender runs observance activities on an MNC, 
which determines a $\mathrm{HC}$ with probability $\beta$. At the same time, an MNC can obtain a payoff equal to $\mathrm{P}$ if engaged in sanction-bursting without being detected and P-F if detected whereas its payoff is expected to be equal to $\mathrm{U}$ as sanctions-compliant. It is assumed that $\mathrm{P}>\mathrm{U}$.

On the other hand, the sender enacts a legal framework as well as promotes compliance campaigns with a total cost of $\mathrm{S}$, such as $\mathrm{S}>0$ to achieve a probability $\beta$ to detect, to expose and to penalize sanctions-bursting activities by an MNC. The sender expects to obtain an economic payoff ${ }^{5}$ equal to A if an MNC is sanctions-compliant and a net economic benefit of A - S after deducting its enforcement and campaigning costs. The sender sets a fine $(\mathrm{F})$ at a level high enough to prevent sanctions-bursting so that $\mathrm{F}>\mathrm{P}$. The sender can obtain, at least, an economic payoff of $\mathrm{E}$ from an $\mathrm{MNC}$ if the sender follows a $\mathrm{LC}$ detection policy. For simplicity, it is assumed that $\mathrm{S}=0$ under the latter policy.

Considering the previous scenarios, the net benefits for both parties can be expressed as a 2 by-2 simultaneous-move game stated in Table 2 by analogy to the Rasmusen's auditing games:

Table 2. Sanctions-bursting game by an MNC in a target country

\begin{tabular}{|l|c|c|c|}
\hline & \multicolumn{3}{|c|}{ MNC } \\
\hline \multirow{3}{*}{ Sender } & & SB( $\boldsymbol{\alpha})$ & SC(1- $\boldsymbol{\alpha})$ \\
\cline { 2 - 4 } & HC $(\boldsymbol{\beta})$ & $(\mathrm{A}-\mathrm{S}, \mathrm{P}-\mathrm{F})$ & $(\mathrm{A}-\mathrm{S}, \mathrm{U})$ \\
\cline { 2 - 4 } & $\mathbf{L C}(\mathbf{1 - \beta})$ & $(\mathrm{E}, \mathrm{P})$ & $(\mathrm{A}, \mathrm{U})$ \\
\hline
\end{tabular}

Source: Author's own elaboration.

The game in Table 2 is a discoordination game with mixed rather than pure strategies for its equilibrium. The equilibrium can be obtained by equating the strategies followed by each player:

\footnotetext{
${ }^{5}$ If MNCs act in compliance with sanctions then economic sanctions are expected to last shorter until obtaining the desirable results aimed by the sender, increasing future expected returns to the sender (through tax and tariffs revenues, etc) from normal dealings of MNCs with previously sanctioned targets.
} 
a. For the MNC: their profits under sanctions-bursting $\left(\pi_{S B}\right)$ and under sanctionscompliance $\left(\pi_{S C}\right)$ are expressed as follows:

Expected sanctions-bursting profits:

$$
E\left(\pi_{S B}\right)=(\mathrm{P}-\mathrm{F}) \beta+\mathrm{P}(1-\beta)
$$

Expected sanctions-compliance profits:

$$
E\left(\pi_{S C}\right)=\mathrm{U}
$$

Then, (III) and (IV) are equated to achieve the optimal situation for an MNC facing both scenarios in expression (V), so it can be indifferent between them:

$$
E\left(\pi_{S B}\right)=\mathrm{E}\left(\pi_{S C}\right)
$$

By replacing (III) and (IV) in (V), the following re-expression for (V) can be obtained in (VI):

$$
(\mathrm{P}-\mathrm{F}) \beta+\mathrm{P}(1-\beta)=\mathrm{U}
$$

Expression (VI) can be rearranged to obtain an expression for the determinants of $\beta$, as the optimal conspicuity detection probability $\beta^{*}$ in (VII), which should make an MNCs indifferent between sanctions-bursting and sanctions-compliance:

$$
\beta^{*}=(\mathrm{P}-\mathrm{U}) / \mathrm{F}
$$

b. For the sender: its profits under high-conspicuity detection $\left(\pi_{H C}\right)$ and low-conspicuity detection $\left(\pi_{L C}\right)$ policies are stated in (VIII) and (IX):

Expected profits from a high-conspicuity detection policy:

$$
\pi_{H C}=\mathrm{A}-\mathrm{S}
$$

Expected profits from a low-conspicuity detection policy:

$$
\pi_{L C}=\mathrm{E} \alpha+\mathrm{A}(1-\alpha)
$$

Then, expressions (VIII) and (IX) are equated in (X) to express an indifferent scenario for the sender between both detection policies: 


$$
\pi_{H C}=\pi_{L C}
$$

Expression (X) is re-expressed by replacing both sides by (VIII) and (IX) to obtain (XI):

$$
\mathrm{A}-\mathrm{S}=\mathrm{E} \alpha+\mathrm{A}(1-\alpha)
$$

Expression (XI) is rearranged to obtain a function for the determinants of the optimal probability, $\alpha^{*}$, of sanctions-bursting by an MNC, yielding:

$$
\alpha^{*}=\mathrm{S} /(\mathrm{A}-\mathrm{E})
$$

As expressed in (XII), the optimal strategy to be followed by an MNC is related to the level S of compliance-detection costs for the sender. A lower level of $\mathrm{S}$ to achieve a given probability $\beta$ of conspicuity detection, leads to a lower sanction-bursting probability $\alpha$ by an MNC, since it will be cheaper to detect its sanctions bursting activities.

In order to ensure this equilibrium, the sender should focus its auditing efforts on a consistent proportion of MNCs that had been engaged with the target before imposing sanctions. This proportion should be also consistent with the track record that the sender keeps in its sanctions-detection efforts. If an MNC is aware that a sender is focused on auditing a proportion of MNCs lower than $\beta^{*}$, such as $\beta=0$, then the MNC is likelier to engage in sanctions-bursting with probability $\alpha=1$ considering that $\mathrm{P}>\mathrm{U}$, namely, its payoff under sanctions-bursting practices $(\mathrm{P})$ will be higher that its payoff following sanctions-compliance practices (U). If a sender knows this reaction by the MNC, then the sender will pursue a higher level of $\beta$, such as $\beta=1$, which is also known by the MNC and will procure not to engage in sanctions bursting with $\alpha=0$. But the latter reaction is also known by the sender that will procure a lower $\beta$ and the MNC will react to it with $\alpha=1$. These reactions will be repeated successively without achieving an equilibrium. 
Within this dynamic between senders and targets, MNCs might attempt to consider different strategic approaches to mitigate the effects of these sanctions on their operations, which will be reviewed in the next section.

\section{MNCs' risk management tactics under country economic sanctions for political aims}

In the management of political risks, MNCs follow different strategies to reduce their potential losses as well as the occurrence probabilities. Those strategies traditionally correspond to the following approaches (Brink 2004; Gregory 1988): a) Integrative strategies, and b) Protective -defensive strategies.

Integrative strategies are focused on mitigating the potential adverse impact of political risk factors on corporates by reducing their likelihood. This is mostly achieved by lobbying practices with host governments where MNCs operate and integrating their practices to the local market conditions and regulations to reduce the frequency of local hostilities towards companies that, otherwise, may be perceived as foreigners or allied to national enemies.

On the other hand, the use of protective-defensive strategies is oriented to minimize the magnitude of total losses arising out of political events in the host country such as expropriations, confiscations, foreign exchange controls, etc. These strategies procure to reduce their aggregated losses through the diversification of MNCs' functional areas and supply chains across different jurisdictions worldwide.

The main concern to choose among those strategies has been traditionally centered around risks emerging from governments in the host countries where MNCs operate. Especially, after an expropriation or confiscation of MNCs' operations, MNCs may lose their control on the local production of key goods or services for their supply chains. As alternative to obtain their needed supplies, MNCs can follow trading with those operations under new owners. 
However, these transactions are likely to be banned under the current context of economic sanctions on a growing number of target governments in countries where those operations are based, which may produce a significant collapse to MNCs' global activities. This concern for MNCs is reflected in Table 3, which reports the top political risks for their operations based on a survey by Oxford Analytica and Willis Towers Watson in 2019 among top MNCs:

Table 3. Main political risk concern in 2019 for MNCs

\begin{tabular}{|l|c|}
\hline \multicolumn{1}{|c|}{ Risk } & \% of total responses \\
\hline Trade sanctions or import/export embargo & 31 \\
\hline Political violence or forced abandonment & 22 \\
\hline Currency transfer restrictions or inconvertibility & 17 \\
\hline Expropriation or creepy expropriation & 14 \\
\hline Sovereign non-payment & 9 \\
\hline Others & 7 \\
\hline
\end{tabular}

Source: Oxford Analytica and Willis Towers Watson (2019)

The previous survey was conducted in a group of MNCs across different industries from developed countries (the US, Europe and Japan), mostly at the top 500 Fortune companies according to their revenues, obtaining responses from 41 of these companies. In this group, $61 \%$ of the firms affirm that their levels of political risk have increased since 2018, mainly due to the imposition of economic sanctions on countries such as Iran, Russia and Venezuela. Trade sanctions is at the top of this list, displacing other risks that have been traditionally rated as more concerning, such as expropriation and currency inconvertibility (Oxford Analytica and Willis Towers Watson 2017).

In all cases, MNCs procure to avoid the use of direct financial transactions using conventional international institutions as the existing bureaucracy responsible for the supervision of sanctions compliance can track them more easily though financial institutions. This bureaucracy is highly specialized in the United States and in the European Union (Freshfields Bruckhaus Deringer 2017). 
In the United States, the Office for Foreign Assets Control (OFAC) issues the Specially Designated Nationals and Blocked Person List (SDN List) containing the names of persons and entities that are banned from engaging in business deals with US nationals. In relation to the European Union, its sanctions are implemented as follows: a) in compliance with Resolutions by the UN Security Council under Chapter VII of the UN Chapter, b) according to the Common Foreign and Security Policy (CFSP) under Article 29 of the Treaty on the Functioning of the European Union (TFEU) and implemented at EU or national levels in conformity with CFSP Council Decisions whenever those involve arms embargoes or admission restrictions. The responsibility to impose penalties for sanctions breaches corresponds to EU Member States rather than to EU Institutions. It also involves the issuance of lists of sanctioned entities and individuals. Financial institutions in the US and the EU have to verify any transaction with those mentioned in these lists, otherwise they may face civil and criminal penalties.

If MNCs insist on dealing with targets whose governments are deemed as violators of human rights, then, they are more likely to face boycotts from their consumers and sizable sanctions from senders. In this case, MNCs might prefer to use strategies in their operations with target countries that contribute to reduce their visibility to the international public opinion. Among these strategies, the following ones can be identified: abiding to international ethical standards, use of alternative suppliers from non-sanctioned countries, trading triangulation practices, changes in transport practices, exiting their investments in the sanctioned countries, use of offshore investment vehicles to avoid sanctions, exploiting loopholes in the enactment of those sanctions, lobbying with the sender to be granted sanctions exceptions and use of risk financing products to cover losses from political risks. 
MNCs might abide to international ethical standards conducting their businesses regardless their jurisdictions. From this perspective, Kakutami (2017) stresses that the public opinion in the sender country as well as in non-sanctioning third countries do not necessarily support sanctions imposed by senders on targets. People from the sender country can show indifference or consider that these sanctions may be unfair with MNCs engaged with the target, minimizing the impact of consumer boycotts that might add to losses imposed by senders. By following international ethical standards, MNCs could be well positioned with the public opinion to manage their reputational risk for their dealings with sanctions targets. This observance is particularly important to EMNCs if they are interested in improving their business reputation in developed countries. Among those standards, it is important to consider guidelines such as the UN Guiding Principles on Business and Human Rights (UNHR 2011) as well as the OECD Guidelines for Multinational Enterprises (OECD 2000). These guidelines are mainly aimed at the best practices dealing with potential or already troubled countries. MNCs should observe those guidelines whenever these confer superior rights ${ }^{6}$ than those under local laws.

The use of alternative suppliers from non-sanctioned countries can be an effective mechanism for MNCs depending on the characteristics of their required goods or services. This practice is advisable for the procurement of non-commodity goods and services whose origin can be easily tracked by parties related to the sender.

On the other hand, the extraterritoriality of many sanctions, like those imposed on Iran by the US, might lead to sanctions on suppliers from non-sanctioned countries that already deal with

\footnotetext{
${ }^{6}$ Rights such as child labor, dealings with irregular/armed groups, etc.
} 
sanctioned countries. This reach might also affect MNCs that deal with these alternative suppliers, demanding a more intensive due diligence on their current or potential suppliers. Trading triangulation practices are used to avoid direct linkages with targets. Through those practices, MNCs purchase goods or services to a vehicular non-sanctioned party under their control that is able to trade with a target. The non-sanctioned party arranges for the delivery of those supplies to MNCs operating under the sender's jurisdictional reach. For goods that are considered as commodities it is simpler to avoid any trace to identify their origin as it is possible to mix commodities to produce a blended variety that can evade chemical controls, such as the coal exports by South African producers under the anti-Apartheid sanctions. A solution to mitigate those practices called for the requirement of "mining origin certificates" at customs declarations (International Labour Office 1992).The same avoidance can be applied in the case of services with a non-tangible nature such as back office support, provision of labor force and others, especially if their origin cannot be tracked through technological devices, etc.

There is an intense international campaign to detect these kinds of practices among MNCs. A recent example of this practice was evidenced with the Chinese MNC Huawei in 2018, which has been accused by US authorities of using non-declared related companies in Hong Kong and Mauritius to directly sell goods with US components to Iran and Syria. Those components had been banned for sale to Iran and Syria under current US sanctions. ${ }^{7}$

In relation to changes in transport practices, some authors (Davarzani, Zanjirani and Rahmandad 2015) have found evidence of MNCs constantly changing transport modes and

\footnotetext{
${ }^{7}$ Stecklow, S.; Dehghanpisheh, B. and Pomfret, J. 2019. "Exclusive: New documents link Huawei with suspected front companies in Iran, Syria." Reuters, January 9. Accessed March 20, 2020. https://www.reuters.com/article/ushuawei-iran-exclusive/exclusive-new-documents-link-huawei-to-suspected-front-companies-in-iran-syriaidUSKCN1P21MH.
} 
routes for their provision of critical items to make more difficult their tracking. Those changes are attributed to more intense checking by customs authorities on direct deliveries to or from targets. These limitations also involve cargo insurers, which are less willing to cover deliveries related to target countries, increasing the insurance costs for these operations as a more limited number of insurers will be willing to underwrite these cargoes.

At the same time, MNCs might consider exiting their investments in target countries to avoid sanctions. Their exit can be voluntary or forced under sanctions enactments and should take into account their assessment on how long these sanctions are expected to last according to the sanctions' ambitiousness.

Their exit can comprise the sale of their local operations to domestic or international nonaffected players by these sanctions. Domestic players might be closely related to local elites that are supposed to be affected by these sanctions (Kaempfer and Lowenberg 2007). In other instances, MNCs can consider the sale of their local operations to their local employees under Employee Buyout (EBO) transactions and similar practices involving local parties.

Another exit mechanism could include the liquidation of different assets corresponding to their local operations. However, local governments could ban this exit strategy and temporarily occupy local MNCs' premises in order to avoid any activity that may be regarded as deindustrializing. These occupation practices have been evidenced in countries such as Venezuela, where the local government under the Chavez and Maduro's administrations took over premises of MNCs such as Kellogg's, Clorox, etc., to avoid the disposal of their assets and their dismantling, which may disrupt their provision of goods to the local market. ${ }^{8}$

\footnotetext{
${ }^{8}$ BBC. 2018. "Venezuela: Kellogg, fabricante de los corn flakes, cesa sus operaciones en el país tras más de un siglo". BBC, May 16. Accessed March 20, 2020. https://www.bbc.com/mundo/noticias-america-latina-44134446.
} 
In all cases, it is expected that those sales will be closed at undervalued prices. If their new owners are related to the ruling elites, then, these elites could procure their acquisition with a sanction-rent-seeking goal as they will be facing fewer competitors from abroad operating in the local market, making the imposition of sanctions more unlikely to inflict damages on that elite.

Many MNCs could also set offshore investment vehicles outside the jurisdictional reach of the sender. These vehicles can act as direct holders of the MNCs' operations in the target. In this way, MNCs procure to avoid direct forced divestments in the target. In addition, the ideal jurisdictions for this purpose are those that have entered into Investment Protection Treaties with the target's jurisdiction. In general, these treaties are aimed at procuring investment protection guaranties to MNCs from the target's authorities against risks such as expropriation and confiscation under their jurisdiction.

The protection against forced divestments in targets under economic sanctions should be incorporated into these treaties whenever one of their parties acts as a sender imposing sanctions on the other party, which may affect operations of MNCs from the sender in the target's jurisdiction. Senders could also include the granting of tax and other incentives to their affected MNCs as compensation for their restrictions to deal with sanctioned countries. By exploiting loopholes, MNCs also procure to use unclear wordings and waivers in economic sanctions to keep dealing with the target. ${ }^{9}$ Among these common loopholes the following ones can be cited: allowances to continue preexisting businesses with the target as technical assistance, use of payments mechanisms not considered under sanctions (use of

\footnotetext{
${ }^{9}$ Some loopholes allow foreign MNCs' subsidiaries to keep dealing with targets. However, under the Iran Threat Reduction and Syria Human Rights Act of 2012 (US Congress 2012) US MNCs may become liable if their foreign subsidiaries violate US sanctions on those countries.
} 
local currencies and cryptocurrencies as described by Abraham 2018), ${ }^{10}$ employment of labor force from the target countries in non-sanctioned jurisdictions, bartering between countries, among others. ${ }^{11}$

In addition to the identification of loopholes, MNCs may also procure sanctions exceptions through lobbying practices on the basis of livelihood exceptions, among other considerations. These exceptions are granted through the issuance of licenses to follow trading with targets. For example, in the case of exceptions granted by the US Office of Foreign Assets Control (OFAC) on US sanctions to different targets such as Cuba, Iran and Sudan, more than 10,000 licenses to approximately 4,000 US MNCs had been granted under the Bush and Obama administrations. ${ }^{12}$ These licenses allow business dealings with those targets amounting to more than USD 1Bn under "humanitarian" exceptions. A closer look at these exceptions by Becker (2010) shows deals in different areas from medical and food items to tobacco and entertainment. This evidence reveals a high flexibility in the granting of these licenses, mainly benefiting MNCs from the sender.

Further to the previous tactical moves by MNCs, it is important to consider the role of political risk insurance to mitigate the loss impact on MNCs from their trade flows and investments in target countries. From this perspective, it represents a costlier risk transfer mechanism in comparison to Investment Protection Treaties. Among the most active

10 Abraham, Chris. 2018. "Sanctioned Countries looking to cryptocurrencies to bypass embargoes." Newconomy.media, September 9. Accessed March 20, 2020 .https://newconomy.media/news/sanctioned-countrieslooking-to-cryptocurrency-to-bypass-embargoes/.

11 The use of workers from the target in non-sanctioned jurisdictions, who may be forced to send remittances to the target's authorities such as in the case of North Korean workers working in neighboring countries such as China (BBC. 2017."How does North Korea do business under sanctions?." Reality Check, BBC. December 29. Accessed March 20, 2020. https://www.bbc.com/news/world-asia-pacific-42314219).

12 Becker, Jo. 2010. "Licenses granted to US companies run the gamut." New York Times. December 24. Accessed March 20, 2020 https://archive.nytimes.com/www.nytimes.com/interactive/2010/12/24/world/24sanctions.html?_r=0 
providers of this type of insurance, the following ones can be cited: MIGA (Multilateral Investment Guarantee Agency) of the World Bank Group, ATI (African Trade Insurance Agency), the Asian Development Bank, the Inter-American Development Bank, ICIEC (Islamic Corporation for the Insurance of Investment and Export Credit), Lloyd's of London syndicates, Export Credit Agencies (ECAs) of many countries as well as private insurers such as American International Group, Zurich Re, Munich Re, Hannover Re, General Re, Sompo International and Sovereign Risk Insurance, mostly members of The Berne Union, which currently reports more than 80 members (The Berne Union 2020). Their typical covers comprise risks arising from the host country of insured investments and exports: political violence in the host country (terrorism, civil unrest, war and the alike), expropriation and confiscation of assets, contract frustration by local governments, wrongful calling of financial guarantees, inability to repatriate funds and business Interruption (The Berne Union 2020; MIGA 2011).

The use of this insurance could be useful for MNCs to cover their investments in countries that are not included under Investment Protection Treaties. In addition, this insurance could provide a safer risk financing mechanism in cases of affected investments in target countries whose governments are financially constrained to settle losses arising from political risks considered in investment protection treaties.

However, the current coverage offerings for MNCs' losses from economic sanctions on target countries is very limited by the previously mentioned carriers. Mostly private carriers such as Axa (France), Sovereign Risk Insurance (Bermuda) and Sompo (Japan) publicly announce a limited and tailor-made cover to protect against financial losses under trade embargoes as at the first quarter of 2019 (AXA 2019; Sovereign Risk Insurance 2019; Sompo International 
2019). ECAs from sender countries are less likely to provide this kind of cover for their MNCs as the main backers of these agencies are the senders' governments imposing these sanctions.

On the other hand, the traditional offering of political risk insurance requires the underwriting of these risks before committing any investment or trade transaction. It turns to be difficult to obtain this cover for investments already undertaken by MNCs. Under this circumstance, MNCs should understand how to assess their expected losses for their dealings with current or potential targets after the imposition of economic sanctions This assessment enables them to self-insure against the impact of these risks on their preexisting investments and trade dealings.

In addition to the previous difficulties, one of the main critics to the use of insurance is related to its likely incidence on a riskier behavior by insureds once covered by an insurance policy. From this perspective, it is also important to assess how the availability of political risk insurance to cover losses from country economy sanctions might encourage MNCs to engage more often in dealings with potential targets. This patterns in plausible considering the previous research by Afesorgbor (2019), who evidenced an increase in trade deals with target countries in the threat phase. Given this evidence, the imminence of sanctions might encourage MNCs to procure insurance coverage against this risk.

In order to understand the effect of insurance on an MNC's engagements with a target (prior to sanctions) in trade deals, the following game theoretic framework is considered:

MNC's behavior without insurance availability: 
In this case, the MNC have two strategies: engage with a potential target with probability $\gamma$ and not to engage with probability $1-\gamma$. The $\mathrm{MNC}$ is assumed as a risk-neutral agent, able to diversify its risks across different geographical markets.

The sender has two choices in this game: impose sanctions with a probability equal to $\mathrm{y}^{*}$ (in equilibrium as expressed in equation II) and not to impose them with probability $1-\mathrm{y}^{*}$.

The payoff matrix for this game without insurance is represented as follows in Table 4:

Table 4. Engagement of an MNC with a target country without insurance

\begin{tabular}{|c|c|c|c|}
\hline & & \multicolumn{2}{|c|}{ MNC } \\
\hline \multirow{4}{*}{ Sender } & & $\begin{array}{c}\text { Engagement } \\
(\gamma)\end{array}$ & $\begin{array}{c}\text { No engagement } \\
(1-\gamma)\end{array}$ \\
\cline { 2 - 4 } & $\begin{array}{c}\text { Sanctions } \\
\left(\mathbf{y}^{*}\right)\end{array}$ & $(\mathrm{M}-\mathrm{S},-\mathrm{L})$ & $(\mathrm{M}-\mathrm{S}, 0)$ \\
\cline { 2 - 4 } & $\begin{array}{c}\text { No sanctions } \\
\left(1-\mathbf{y}^{*}\right)\end{array}$ & $(\mathrm{T}, \mathrm{P})$ & $(\mathrm{R}, 0)$ \\
\hline
\end{tabular}

Source: Author's own elaboration.

Where M, T and R are the payoffs to the sender under different scenarios. In the scenario of sanctions imposition, the sender faces a cost of $\mathrm{S}$ to ensure sanctions compliance. The payoffs for the MNC are $-\mathrm{L}$ (cost of sales), $\mathrm{P}$ (including cost of sales and mark-up), whereas its payoff amounts to 0 if not engaged with a target.

The expected payoff to an MNC engaging without insurance $\left(\pi_{\mathrm{EWI}}\right)$ with a target is:

$$
\mathrm{E}\left(\pi_{\mathrm{EWI}}\right)=-\mathrm{Ly} *+\mathrm{P}\left(1-\mathrm{y}^{*}\right)
$$

For this game with insurance covering an $\mathrm{MNC}$ for its engagements with a target, its corresponding payoff matrix is expressed in Table 5: 
Table 5. Engagement of an insured MNC with a target country

\begin{tabular}{|c|c|c|c|}
\hline 3 & & \multicolumn{2}{|c|}{ MNC } \\
\hline \multirow{3}{*}{ Sender } & & $\begin{array}{c}\text { Engagement } \\
(\gamma)\end{array}$ & $\begin{array}{c}\text { No engagement } \\
(1-\gamma)\end{array}$ \\
\hline & $\begin{array}{c}\text { Sanctions } \\
\left(\mathrm{y}^{*}\right)\end{array}$ & {$\left[\mathrm{M}-\mathrm{S},-\left(\mathrm{y}^{*}+\mathrm{e}_{1}\right) \mathrm{L}\right]$} & $(\mathrm{M}-\mathrm{S}, 0)$ \\
\hline & $\begin{array}{c}\text { No sanctions } \\
\left(1-y^{*}\right)\end{array}$ & {$\left[\mathrm{T}, \mathrm{P}-\left(\mathrm{y}^{*}+\mathrm{e}_{1}\right) \mathrm{L}\right]$} & $(\mathrm{R}, 0)$ \\
\hline
\end{tabular}

Source: Author's own elaboration.

In this case, the MNC pays a premium for $\left(\mathrm{y}^{*}+\mathrm{e}_{1}\right) \mathrm{L}$, where $\mathrm{L}$ is the insured amount (cost of sales), the term $\left(y^{*}+e_{1}\right)$ corresponds to the premium rate considering the optimal sanction enforcement probability as in (II) and $\mathrm{e}_{1}$ corresponds to a mispricing factor due to asymmetric information between the insurance underwriter and the sender in relation to the probability of sanction imposition. The insured $\mathrm{MNC}$ might perceive $\mathrm{e}_{1}$ and procure to take advantage of this mispricing whenever its expected payoffs with insurance are superior to those without insurance.

The expected payoff to an MNC covered with insurance to engage with a target $\left(\pi_{\mathrm{EI}}\right)$ is:

$$
\mathrm{E}\left(\pi_{\mathrm{EI}}\right)=-\left(\mathrm{y}^{*}+\mathrm{e}_{1}\right) \mathrm{Ly} \mathrm{y}^{*}+\left[\mathrm{P}-\left(\mathrm{y}^{*}+\mathrm{e}_{1}\right) \mathrm{L}\right]\left(1-\mathrm{y}^{*}\right)
$$

The MNC will be better-off if its expected payoff with insurance is superior to its payoff without insurance, as follows:

$$
\mathrm{E}\left(\pi_{\mathrm{EI}}\right) \geq \mathrm{E}\left(\pi_{\mathrm{EWI}}\right)
$$

Replacing (XIII) and (XIV) in (XV):

$$
-\left(\mathrm{y}^{*}+\mathrm{e}_{1}\right) \mathrm{Ly} \mathrm{y}^{*}+\left[\mathrm{P}-\left(\mathrm{y}^{*}+\mathrm{e}_{1}\right) \mathrm{L}\right]\left(1-\mathrm{y}^{*}\right) \geq-\mathrm{Ly} *+\mathrm{P}\left(1-\mathrm{y}^{*}\right)
$$

Expression (XVI) can be rearranged to obtain the range of values for the insurance carrier's mispricing factor, $\mathrm{e}_{1}$ :

$$
\mathrm{e}_{1 \leq 0}
$$


The mispricing factor most be strictly equal to or lower than 0 for the MNC to be better-off with insurance coverage when dealing with target countries before any sanctions imposition. The feasibility of this cover requires limiting or suspending its coverage once sanctions are imposed on a target, especially if these sanctions have an extraterritorial reach on an MNC that might demand this kind of insurance.

In this case, it has been assumed that the insured is unable to influence the probability of sanction imposition by the sender, which is different to other kinds of insurance covers in which insureds can influence the loss occurrence probability with their misbehavior after obtaining insurance cover (moral hazard). This assumption can be modified whenever an MNC can influence the sender's decision to enforce sanctions on a target without any involvement of the insurer, such as forcing a target to introduce changes that might benefit an $\mathrm{MNC}$ once it has been granted insurance coverage. In this latter scenario, $\mathrm{e}_{1}$ might also reflect this effect.

Further to the use of insurance, it is also important to explore new risk financing mechanisms to cover country sanctions-related risks in the alternative risk transfer market through the use of capital markets instruments to transfer these risks from MNCs. At the moment, a manmade risk like terrorism is expected to be traded in capital markets with catastrophe bonds and the same kind of instrument could be used to cover other political risks. ${ }^{13}$ It could be also possible to hedge sanctions-related risks with the Insurance Linked Securities (ILS) by making use of generally accepted indexes tracking these risks such as it has been attempted to

\footnotetext{
${ }^{13}$ Terrorism risk is expected to be covered through capital markets with the issuance of CAT bonds by Pool Re, a UK government-backed mutual terrorism reinsurance facility ("Pool Re sponsors first terrorism risk catastrophe bond, Baltic PCC." 2019. Artemis.bm, January 14. Accessed March 20, 2020. http://www.artemis.bm/news/pool-responsors-first-terrorism-risk-catastrophe-bond-baltic-pcc/).
} 
cover another man-made risk like cyber risk. ${ }^{14}$ The development of tracking indexes in the political risk area might be possible through the use of modern technologies making use of Artificial Intelligence and Machine Learning breakthroughs developed by InsurTech companies. One of these companies is GeoQuant, which has developed a software that applies these technologies and whose output is an index that reflects political risk levels in real time (GeoQuant 2019). The levels of this index could be used as triggers for the payment of payouts to the holders of these securities.

\section{Conclusions and future directions}

From the previous literature review, it is important for MNCs to take into account the elements that may lead to the imposition of economic sanctions on each country where they plan to start operations or are already operating as well as to assess their impact for potential senders and targets under different scenarios by using a game theoretical framework like the one proposed by Tsebelis (1990). This framework is suitable to understand the evolving pattern of man-made risks, like this political risk, and to assess the optimal sanction enforcement probability that influences the expected losses for MNCs whenever they decide to avoid further dealings with already sanctioned targets.

Once MNCs decide to keep dealing with targets (such as in the case of EMNCs and SOEs from emerging-market countries) their conspicuity detection $(\beta)$, according to the previous enhancement of the Kakutami's model, demands their attention to the sustained senders' track record in their sanctioning efforts as well as to MNCs' management of their reputational risk,

\footnotetext{
${ }^{14}$ PCS has developed a PCS Global Cyber Index that can be used as trigger to determine payoffs corresponding to ILS related to cyber risks ( "PCS aims to help understanding of the silent side of cyber risk: Johansmeyer." 2018. Artemis.bm, September 10. Accessed March 20, 2020. http://www.artemis.bm/news/pcs-aims-to-helpunderstanding-of-the-silent-side-of-cyber-risk-johansmeyer/).
} 
regardless their optimal sanction-bursting levels. This detection seems to be of less concern for many $\mathrm{MNCs}$ from developing countries, more prone to employ non-market entry strategies into developing countries to reduce their observance to many regulations that, otherwise, they must meet in the context of developed countries, as suggested by different authors (Garcia-Canal and Guillen 2008; Kobrin 2009; Li and Gaur 2014; Salazar et al. 2018). A mismanagement of this risk might also expose MNCs to further losses from consumer boycotts. The intensity of these boycotts is expected to be highly related to the values that are shared by the public opinion in the sender country as well as in the target country and third countries where MNCs operate. A robust way for MNCs to minimize the impact of this risk is by conducting their operations in compliance with high corporate and social responsibility standards such as the ones suggested under the UN Guiding Principles on Business and Human Rights (UNHR 2011) as well as the OECD Guidelines for Multinational Enterprises (OECD 2000).

At the same time, a decrease of the senders' costs to detect sanctions-bursting activities for any level of conspicuity detection should lead MNCs to follow a more sanctions-compliant behavior whenever they act as profit maximizers and interested in keeping the possibility to deal with senders. Otherwise, MNCs might act pursuing other purposes to keep dealing with a growing number of targets, such as geopolitical interests or due to the impossibility to compete in markets under the sender's jurisdictions, as revealed by EMNCs and SOEs from emerging market countries.

Facing the possibility of penalties for their dealings with targets, MNCs should make the decision either to keep operations with the target or to assume losses from their temporal or permanently exit from these operations or to even transfer those risks to third parties. They 
can pursue different strategies to retain these risks by reducing the visibility of their direct dealings at high reputation risk costs, recurring to lobbying practices to be granted sanctions exceptions or transferring those risks to third parties. The transfer of this risk demands updates to Investment Protection Treaties to include trade and investment losses due to economic sanctions when one of the parties acts as a sender. The use of political risk insurance as traditional risk transfer mechanism of political risks also requires its adjustment to include MNCs' losses arising from these sanctions. In addition, the use of capital markets to transfer this risk can be also explored by promoting the issuance of instruments such as catastrophe bonds and Insurance Linked Securities using triggers related to these risks.

The feasibility of these instruments should consider the assessment of this risk by exploring the different elements that may lead to the imposition of sanctions as discussed in this article. Of particular importance is the understanding of the use of insurance as risk financing instrument as it could encourage moral hazard in the behavior of insureds (MNCs) whenever they have privileged information on the likelihood of sanction impositions by senders in comparison to the insurance providers. This risk requires adjustments to the design of insurance contracts, such as the use of deductibles, to discourage moral hazard.

For further research, it is recommended to explore business cases and empirical evidence on how the growing presence of EMNCs in many target countries, the increase in the number of target countries dealing among them and the use of financial mechanisms outside the traditional international financial systems, such as cryptocurrencies, are contributing to reduce the effectiveness of the current types of trade and financial sanctions. This comprehension is important as senders might react to these trends with countermeasures such as extraterritorial sanctions involving all kind of dealings with targets that might affect third parties indirectly 
related to targets. The reach of these extraterritorial sanctions also demand the use of methodologies such as network graphs and others to explore the levels of interconnectedness among different business players that might be negatively affected by these sanctions.

\section{References}

Adesnik, David, and Saeed Ghasseminejad. 2018. "Foreign Investment in Iran: Multinational Firms' Compliance with US Sanctions." Research Memo, Foundation for Defense of Democracies FDD. Accessed December 10, 2019. doi:10.2139/ssrn.3257581.

Afesorgbor, Sylvanus. 2019. "The impact of economic sanctions on international trade: How do threatened sanctions compare with imposed sanctions." European Journal of Political Economy 56:11-26. doi:10.1016/j.ejpoleco.2018.06.002

Axa Insurance. 2019. "Products / Trade Credit Insurance." Accessed December 28, 2019. https://axaxl.com/insurance/products/trade-credit-insurance.

Brink, Charlotte H. 2004. Measuring Political Risk: Risk to Foreign Investment. Ashgate Publishing: Aldershot.

Business \& Sanctions Consulting Netherlands. 2019. "Sanctions Risk List Countries." Accessed December 9. https://www.bscn.nl/en/sanctions-consulting/sanctions-list-countries.

Casanova, Lourdes, and Anne Miroux. 2016. "The rise of emerging market multinationals: this is how they can become global industry leaders." World Economic Forum. Accessed December 9, 2019. https://www.weforum.org/agenda/2016/12/emerging-market-multinationals/.

Davarzani, Hoda, Reza Zanjirani Farahani and Hazir Rahmandad Rahmandad. 2015. "Understanding eco-political risks: Impact of sanctions on an automotive supply chain.” International Journal of Operations and Production Management 35(11): 1567-1591. doi:10.1108/IJOPM-01-2013$\underline{0021 .}$.

Freshfields Bruckhaus Deringer. 2017. "A Regulated World - Sanctions.” Accessed February 16, 2020. https://www.freshfields.com/globalassets/our-thinking/campaigns/sanctions_guide.pdf.

Garcia-Canal, Esteban, Mauro and Guillen.2008. "Risk and the strategy of foreign location choice in regulated industries." Strategic Management Journal 29(10): 1097-1115. doi:10.1002/smj.692

GeoQuant. 2019. "How.” Accessed March 20, 2020. https://www.geoquant.io/

Gomez-Mera, Laura, Thomas Kenyon, Yotam Margalit, José Reis, and Gonzalo Varela. 2014. New Voices in Investment: A Survey of Investors from Emerging Countries. Washington, DC: International Bank for Reconstruction and Development/World Bank, First ed. 
Gregory, Ann. 1988. "Integrative and Protective Techniques in Reducing Political Risk: A Comparison of American and Canadian Firms in Indonesia." In Global Risk Assessment: Issues, Concepts, and Application, edited by Jerry Rogers, 98-116. Riverside: Global Risk Assessments Inc.

Hufbauer, Gary Clyde, Jeffrey J. Schott, Kimberly Elliott, and Barbara Oegg. 2007. Economic Sanctions Reconsidered. Washington, DC: Peterson Institute for International Economics. $3^{\text {rd }}$ Edition.

International Labour Office - ILO. 1992. Study on the embargo of coal exports from South Africa. Report, Geneva: International Labour Office.

Kaempfer, William H., and Anton D. Lowenberg. 2007. "The Political Economy of Economic Sanctions." In Handbook of Defense Economics. Defense in a Globalized World, edited by Todd Sandler and Keith Hartley. Vol. 2, 867-911. doi:10.1016/S1574-0013(06)02027-8.

International Monetary Fund. 2015. "World Economic Outlook - October 2015." Washington D.C.: $\begin{array}{llll}\text { International } & \text { Monetary } & \text { Fund.Accessed } & \text { May }\end{array}$ https://www.imf.org/ /media/Websites/IMF/imported-flagshipissues/external/pubs/ft/weo/2015/02/pdf/ text.ashx

Kakutami, Yuichiro 2017. "MNC Decision Making Under Sanctions: South Africa and Rodhesia." Cornell International Affairs Review 11(1): 102-139.

Kobrin, Stephen J. 2009. "Private political authority and public responsibility: transnational politics, transnational firms and human rights.” Business Ethics Quarterly 19(3): 349-371.

Li, Shaomin, and Ajai Gaur. 2014. "Financial Giants and Moral Pygmies: Multinational corporations and human rights in emerging markets." International Journal of Emerging Markets 9(1): 1132.

Madhok, Annop and Rogerio Marques. 2013. "Competing on Action: Business Models and the Competitiveness of Emerging Market Enterprises." SSRN Working Paper. Accessed December 9, 2019. doi:10.2139/ssrn.2376337.

Multilateral Investment Guarantee Agency - MIGA. 2011. "The Political Risk Insurance Industry.” In, World Investment and Political Risck 2010, 52-72. Washington: Multilateral Investment Guarantee Agency. doi: https:10.1596/978-0-8213-8478-7.

Morgan, T. Clifton, Navin Bapat, and Valentin Krustev. 2009. "The Threat and Imposition of Economic Sanctions, 1971-2000." Conflict Management and Peace Science 26(1): 92-110. doi:10.1177\%2F0738894208097668.

Mourdoukoutas, Panos. 2019. "World's 500 Largest Corporations in 2019: China Matches America." $\begin{array}{lllll}\text { Forbes, } & \text { July } & 23 & \text { Accessed }\end{array}$ 
https://www.forbes.com/sites/panosmourdoukoutas/2019/07/23/worlds-500-largestcorporations-in-2019-china-matches-america/\#53adb0151383.

Organization for Economic Co-operation and Development - OECD. 2000. Guidelines for Multinational Enterprises: Revision 2000. Vol. 2006. Paris: Organization for Economic Cooperation and Development.

Oxford Analytica and Willis Towers Watson. 2017. "How are leading companies managing today's political risk." Survey and Report. Accessed December 15, 2019. https://www.oxan.com/media/1955/oa wtw-political-risk sep-2017.pdf.

Oxford Analytica and Willis Towers Watson. 2019. "How are leading companies managing today's political risk." Survey and Report. Accessed December 15. https://www.willistowerswatson.com/en-US/Insights/2019/12/2019-political-risk-survey-report. Pradiptyo, Rimawan .2007. "Does Punishment Matter? A Refinement of the Inspection Game." Review of Law and Economics 3(2): 197-219. doi:10.2202/1555-5879.1099.

Rasmusen, Eric. 2001. Games and Information: an introduction to games theory. Oxford: Blackwell Publisher, $3^{\text {rd }}$ Edition.

Salazar, Ronald J, Jifu Wang, Rupak Rauniar, and Xiuli Wang. 2018. "A game analysis of MNC CSR in China." Cogent Business \& Management 5(1): 1-13. doi: 10.1080/23311975.2017.1409685.

Sompo International. 2019. "Insurance / London Market and Europe Political \& Financial Risk."

Accessed December 28, 2019. https://www.sompo-intl.com/insurance/london-market-andeurope-political-financial-risk/.

Sovereign Risk Insurance. 2019. "Other customized covers." Accessed March 15. https://www.sovereignbermuda.com/our-products/other-customized-covers/.

The Berne Union. 2020. "Members.” Accessed March 20. https://www.berneunion.org/.

Tolentino, Paz. 2012. "Innovation and Multinational Companies from Emerging Economies: The Search for New Explanations." Paper presented at the Third Copenhagen Conference on "Emerging Multinationals":Outward Investment from Emerging Economies, Copenhagen, Denmark, October 25-26. Accessed March 2020. http://gdex.dk/ofdi12/Paz\%20Estrella\%20Tolentino\%20-\%20Draft\%205.pdf

Transparency International. 2016. "Transparency in Corporate Reporting: assessing emerging markets multinationals." $\quad$ Accessed $\quad$ December 2019. https://issuu.com/transparencyinternational/docs/2016_transparencyincorporatereporti?e=24964 $\underline{56 / 37122985}$

Tsebelis, George. 1990. "Are sanctions effective: A game theoretic analysis." Journal of Conflict Resolution, 34(1):3-28. doi:10.1177/0022002790034001001 


\section{Journal of Evolutionary Studies in Business}

United Nations Human Rights - UNHR. 2011. Guiding Principles on Business and Human Rights.

Implementing the United Nations "Protect, Respect and Remedy" Framework, New York and Geneva: United Nations Human Rights.

US Congress. 2012. "The Iran Threat Reduction and Syria Human Rights Act of 2012." Public Law, 112-158-August 10, 2012, Washington: US Congress. Accessed April 19, 2019. https://www.congress.gov/112/plaws/publ158/PLAW-112publ158.pdf.

World Bank. 2018. "World Bank Country and Lending Groups." Accessed March 5, 2020. https://datahelpdesk.worldbank.org/knowledgebase/articles/906519\#High income. 